\title{
Three new Angiospermic (Orchidaceae) records from Bangladesh
}

\author{
Mohammed Kamrul Huda, Mohammed Mozammel Hoque* and \\ Md. Owahidul Alam \\ Department of Botany, University of Chittagong, Chittagong-4331, Bangladesh
}

\begin{abstract}
Coelogyne schwadtkii Danell., Cleisostoma williamsonii (Rchb.) Garay. and Phalaenopsis difformis (Wall. ex Lindl.) Kocyan \& Schuit. of the family Orchidaceae collected from southeast part of the country have been reported here as new angiospermic records for Bangladesh flora. Detailed critical examination of the specimens of these species has been made to confirm their taxonomic identification. Detailed taxonomic description with flowering time, ecology, geographical distribution, illustration and photographs of each species has been provided.
\end{abstract}

Key words: New records, Coelogyne schwadtkii, Cleisostoma williamsonii, Phalaenopsis difformis, Bangladesh.

\section{INTRODUCTION}

The family Orchidaceae belongs to the Lilliopsida of flowering plants. It is one of the most fascinating groups of ornamental plants of the world occurring mostly in the tropical and subtropical parts of the world with 880 genera and about 26567 species (Cai et al., 2015), a few of them are also found in arctic regions. This family represents 579 species in Bhutan (Pearce \& Cribb, 2002), 1388 species (including 491 endemic) in China (Lang et al., 1999), 1350 species under 185 genera in India (Hegde, 1997), and 450 species in Nepal (Pant et al., 2016). In Bangladesh, the family is represented by 72 genera and 188 species (Rahman et al., 2017). William Roxburgh (1814) for the first time recorded 12 species of orchids in his Hortus Bengalensis (nom. nud.) from Bangladesh and later he described 28 species in his Flora indica (Roxburgh, 1832). Subsequent by Wallich (17861854) recorded 27 species, Hooker (1885-1890; 1890-1894) 79 species, Prain (1903) 74 species, Heinig (1925) 49 species, Datta \& Mitra (1953) 13 species and Sinclair (1956) 19 species around the world. Since the independence of Bangladesh in 1971, a number of workers have made remarkable contributions to the account of the Orchidaceae from its flora, such as, Seidenfaden (1978, 1978a, 1985, 1988), Moyeen (1982), Biswajit (1987), Khan \& Halim (1987, 1991), Halim \& Khan (1991), Ahmed \& Pasha (1993, 1994, 1998, 1998a), Rahman \& Huda (1998, 2001), Huda \& Rahman (1999), Huda et al., (1999, 2001), Khamum et al., (2001), Huda (2007) and Rahman et al., (2017). According to upto date literature, three species of the genus Cleisostoma, five species of Coelogyne and three species of Phalaenopsis have been reported so far from Bangladesh (Huda, 2008). Therefore, three more species under above mentioned three genera have been reported

\footnotetext{
* Corresponding author. Email: mmhoquecu@yahoo.com
} 
here for the first time from Bangladesh. Orchid flora of Bangladesh is not yet prepared completely and it is still being explored. The present work is aimed at discovering unexplored orchids from different remote areas of Bangladesh based on extensive field works towards completion of the orchid flora of Bangladesh.

\section{MATERIALS AND METHODS}

The specimens were collected from the remote areas of Boga Lake Para, Ruma, Bandarban and Shadi beat, Jaflong, Jaintiapor, Jaintia hill, Sylhet district of Bangladesh. The collected plants were grown at the orchidarium. After bloom the flowers of each of the species were dissected and critically examined under microscope and then identified with the consultation of the relevant literature (Prain, 1903; Heinig, 1925; Datta \& Mitra, 1953; Sinclair, 1955; Pearce \& Cribb, 2002; Rahman et al., 2017). The voucher specimens of each species have been deposited at the Herbarium of Chittagong University (HCU), Bangladesh.

\section{RESULTS AND DISCUSSION}

In the present study, three species viz. Coelogyne schwadtkii Danell., Cleisostoma williamsonii (Rchb.) Garay. and Phalaenopsis difformis (Wall. ex Lindl.) Kocyan \& Schuit. have been reported here as new angiospermic record for Bangladesh flora.

\section{Taxonomic description}

1. Coelogyne schwadtkii Danell, Orchideen J. 23: 107 (2016). (Plate 1 and Fig. 1).

\section{Common name: Schwadtke's Eria}

Description: Epiphytic herb. Rhizome creeping, $3 \mathrm{~mm}$ in diameter, covered in persistent bracts. Pseudobulbs erect, cylindrical, tapering slightly to apex $58-76 \mathrm{~mm}, 5-8 \mathrm{~mm}$ wide at base, ribbed and somewhat angular, base with two tightly-embracing sheaths, the largest $26 \mathrm{~mm}$, apex two-leaved, distance between pseudobulbs $1.5-2 \mathrm{~cm}$. Leaves deciduous, suberect, petioles $12-16 \mathrm{~mm}$, blades oblong-elliptic to lanceolate, $86-90 \times 21$ $25 \mathrm{~mm}$, leathery, underside prominently 3-ribbed, green, apex acute. Inflorescence synanthous, emerging from young shoot when leaves start to emerge, erect, very short; peduncles 10-25 mm, green, rachis 1-3 flowered, crowded, green, opening in succession until all are flowering simultaneously, floral bracts persistent, lanceolate, $17 \mathrm{~mm}$, acute. Flower wide-opening to $4 \mathrm{~cm}$ wide x $5.5 \mathrm{~cm}$ high, odourless, sepals and petals pale greenish-yellow; lip cream to pale yellow, side lobes with brown margins and veins, mid lobe brown with cream margins and median stripe, keels white, turning brown on mid lobe; column and anther-cap green. Dorsal sepal erect, not covering the column, ovateelliptic, $32 \times 10 \mathrm{~mm}, 7$ veins, acute. Lateral sepals obliquely descending, decurved, unequally oblong-elliptic, $29 \times 9 \mathrm{~mm}, 5$ veins, externally keeled, acute and acuminate. Petals decurved, linear, $24 \times 1.5 \mathrm{~mm}, 3$ veins, acute. Lip porrect, decurved from middle, $22 \times 12 \mathrm{~mm}$; saccate at base, 3-lobed in centre; side lobes erect, $12 \times 4 \mathrm{~mm}$, free part 
turned outwards, triangular, $4 \times 3 \mathrm{~mm}$, apex rounded; mid lobe clawed at base, $15.5 \times 12$ $\mathrm{mm}$, margins entire, claw transverse rectangular, $5 \times 7.5 \mathrm{~mm}$, blade ovate, $9 \times 12 \mathrm{~mm}$, rounded, terminating abruptly in a $2 \mathrm{~mm}$ decurved point; keels 3 , straight, entire, without ornaments, extending from base of lip to apex, non-undulating, diverging from lip base to lip centre, after which they converge, lateral keels rising from base to $1.5 \mathrm{~mm}$ high at mid lobe base, after which they diminish abruptly and are low, median keel low throughout. Column porrect, arcuate, trigonal in section, $17 \mathrm{~mm}$, broadening to $7 \mathrm{~mm}$ near apex, distal half abaxially keeled and winged along margins, apex hooded, truncate, margin erose.

Flowering and fruiting time: Early February - mid March.

Ecology: The orchid was collected in vegetative stage from Litsea polyantha Juss. plant at the height of approximately $10 \mathrm{~m}$. It was also found to associate with Ferns. Only one or two vegetative parts of the species were found in the area.

Distribution: Thailand (Danell, 2016). In Bangladesh the species is found to occur in Boga Lake Para, Ruma, Bandarban.

Uses: Unknown

Specimen examined: Bandarban: Boga Lake Para, Ruma, 10.04.2018, M.K. Huda, M.M. Hoque, and M.O. Alam 215 (HCU).

Differs from Coelogyne authors species in the synanthous inflorescence, linear petals and non-undulating keels on the lip.

2. Cleisostoma williamsonii (Rchb.) Garay, Bot. Mus. Leafl. 23: 176 (1972). (Plate 2 and Fig. 2).

Synonyms: Sarcanthus williamsonii Rchb(1865); Echioglossum williamsonii (Rchb. f.) Szlach., (1995); Sarcanthus demangei Guillaumin, (1930); Cleisostoma demangei (Guillaumin) Garay (1972); Cleisostoma elongatum (Rolfe) Garay (1972); Cleisostoma hongkongense (Rolfe) Garay (1972); Cleisostoma sacculatum (Ridl.) Garay (1972).

\section{Common name: Williamson's Cleisostom}

Description: Plants often pendulous. Stems to $70 \mathrm{~cm}$, rather slender, 3-4 $\mathrm{mm}$ in diam., branched or unbranched, many leaved, internodes $1-2.5 \mathrm{~cm}$. Leaves straight or slightly arching, terete, usually $6-10 \mathrm{~cm} \times 2-3 \mathrm{~mm}$, obtuse. Inflorescence lateral, ascending, longer than leaves, usually branched, densely many flowered; floral bracts ovatelanceolate, $2 \mathrm{~mm}$. Flowers opening widely, pink, lip deep purple-red; pedicel and ovary 5 $\mathrm{mm}$, slender. Dorsal sepal ovate-elliptic, cymbiform, $2.2 \times 1.5 \mathrm{~mm}$, rounded; lateral sepals obliquely ovate-elliptic, $2.5 \times 1.5 \mathrm{~mm}$, base adnate to column foot, obtuse. Petals oblong, $2.2 \times 1 \mathrm{~mm}$, obtuse; lip lateral lobes erect, ligulate-oblong, obtuse, \pm incurved; mid-lobe narrowly ovate-triangular, fleshy, adaxially with a ridge raised and triangular 
near spur entrance; spur globose, $2 \mathrm{~mm}$ in diam., slightly laterally compressed, concave, interior inconspicuously septate, with a back wall callus; callus 3-lobed, T-shaped; lateral lobules nearly horn-shaped, slightly recurved; mid-lob shallowly bilobed at the base and densely papillate-hairy. Column $2 \mathrm{~mm}$; anther cap truncate, broadly emarginate; stipe broadly ovate-triangular; viscidium nearly crescent-shaped.

Flowering and fruiting time: Mid April - late June.

Ecology: The species usually occur on Dipterocarpus turbinatus Gaertn. tree including other large trees $20 \mathrm{~m}$ high in the evergreen dense forests.

Distribution: Bangladesh, Bhutan, India, Indonesia, Malaysia, Myanmar, Thailand (Williamsoni, 1972). In Bangladesh, the species was recorded from Shadi beat, Jaflong, Jaintiapor, Jaintia hill, Sylhet.

Uses: Headache, numbness and pain (Williamsoni, 1972).

Specimen examined: Sylhet: Shadi beat, Jaflong, Jaintiapor, Jaintia hill, 11.10.2018; M.K. Huda; M.M. Hoque and M.O. Alam, 208 (HCU).

Differs from the other species column with apical stelidia, glabrous;

stipe broadly ovate-triangular or miter-shaped; viscidium crescent-shaped.

\section{Phalaenopsis difformis (Wall. Ex Lindl.) Kocyan \& Schuit. (2014).}

Synonyms: Orinithochilus difformis (Wall. ex Lindl.) Schltr., (1919); Aerides difformis Wall. ex Lindl., (1833). Orithchilus fuscus Wall. ex Lindl., (1833); Hook. f., (1890). (Plate 3 and Fig. 3).

\section{Common name: The Dark Brown Phalaenopsis.}

Description: Epiphytic, stem very short bearing few leaves, 7-16 x 3-4 cm, sessile, spreading, coriaceous, elliptic oblong, acute, flat, narrowed at the base. Inflorescence pendulous, many-flowered, much longer than the leaves, 20-30 cm long. Flowers $1.2 \mathrm{~cm}$ across, greenish-yellow with brown bands. Bracts much shorter than ovary, lanceolate 3 $\mathrm{mm}$ long. Sepals spreading or reflexed, unequal, oblong-ovate, obtuse, yellow, streaked with red. Petals similar to sepals but smaller. Lip much longer than the sepals; apical lobe divided into 3 lobules; side lobes subquadrate, recurved with pectinate margin; central lobule triangular, in fold and with entire margin, abroad long claw and an incurved sub cylindric spur joint to the apical lobe, two calli at the mouth of the spur; column short, cylindric, stout with a short foot; rostellum forked; stigma circular, surrounded by hairy rim attached to the short foot of the column by claw and epichile with 2-lateral recurved pectinate lobules. 
Flowering and fruiting time: Late June- early July.

Ecology: Epiphytic and grows on trees especially on Glochidion velutinum Wight. Trees at $20 \mathrm{~m}$ high altitude, evergreen forest, and large clumps occur on trunk of the trees.

Distribution: Bangladesh, India, China, Nepal, Myanmar and Thailand (Kocyan \& Schuiteman, 2014). In Bangladesh, the species was recorded from Shadi beat, Jaflong, Jaintiapor, Jaintia hill, Sylhet.

Uses: Unknown

Specimen examined: Sylhet: Shadi beat, Jaflong, Jaintiapor, Jaintia hill, 10.10.2019; M.K. Huda, M.M. Hoque, and M.O. Alam 216 (HCU). P. difformis, different characters of three others species of Bangladesh, flowers greenish-yellow with brown bands, lip much longer than the sepals; apical lobe divided into 3 lobules.

Coelogyne schwadtkii belongs to the Section Lentiginosae. Pfitzer \& Kraenzlin (1907) illustrated the lips of all ten species known from this section. Five species viz. C. barbata Griff., C. cristata Lindl., C. flaccid Lindl., C. punctulata Lindl. and C. viscose Rchb. f. was reported in Bangladesh. C. schwadtkii differences from other's five species in having stouter fusiform pseudobulbs, smaller flowers, broader lanceolate petals and wavy keels on the lip.

The genus Cleisostoma Blume. was reputed four species viz. C. lanatum Lindl., C. appendiculatum (Lindl.) Benth. \& Hook. f. and C. filiforme (Lindl.) Garay.in Bangladesh. Cleisostoma williamsonii (Rchb.) Garay. is also differs from the author's species, column with apical stelidia, glabrous; stipe broadly ovate-triangular or mitershaped; viscidium crescent-shaped. $C$. williamsonii (Rchb.) Garay. Is also a widely spread species found throughout the most of Southeast Asia but not reported from Bangladesh.

Phalaenopsis Blume. is a member of the Subtribe Sarcantheae, along with about eighty other genera. Phalaenopsis is rather easily distinguished from the other popular members of the Sarcantheae by its habit, the few leaves being fairly broad, flat and closely borne on a short stem; occasionally. Phalaenopsis Blume. genus comprising four species including the new record of one species $P$. difformis (Wall. Ex Lindl.) Kocyan \& Schuit., along with three earlier species viz. P. cornucervi (Breda) Bl. \& Rchb. f., P. deliciosa Rchb. f. and P. taenialis (Lindl.) E. A., recorded in Bangladesh. P. difformis, different characters of other's species, flowers greenish-yellow with brown bands, lip much longer than the sepals; apical lobe divided into 3 lobules, P. difformis, recorded for the first time in Bangladesh. 


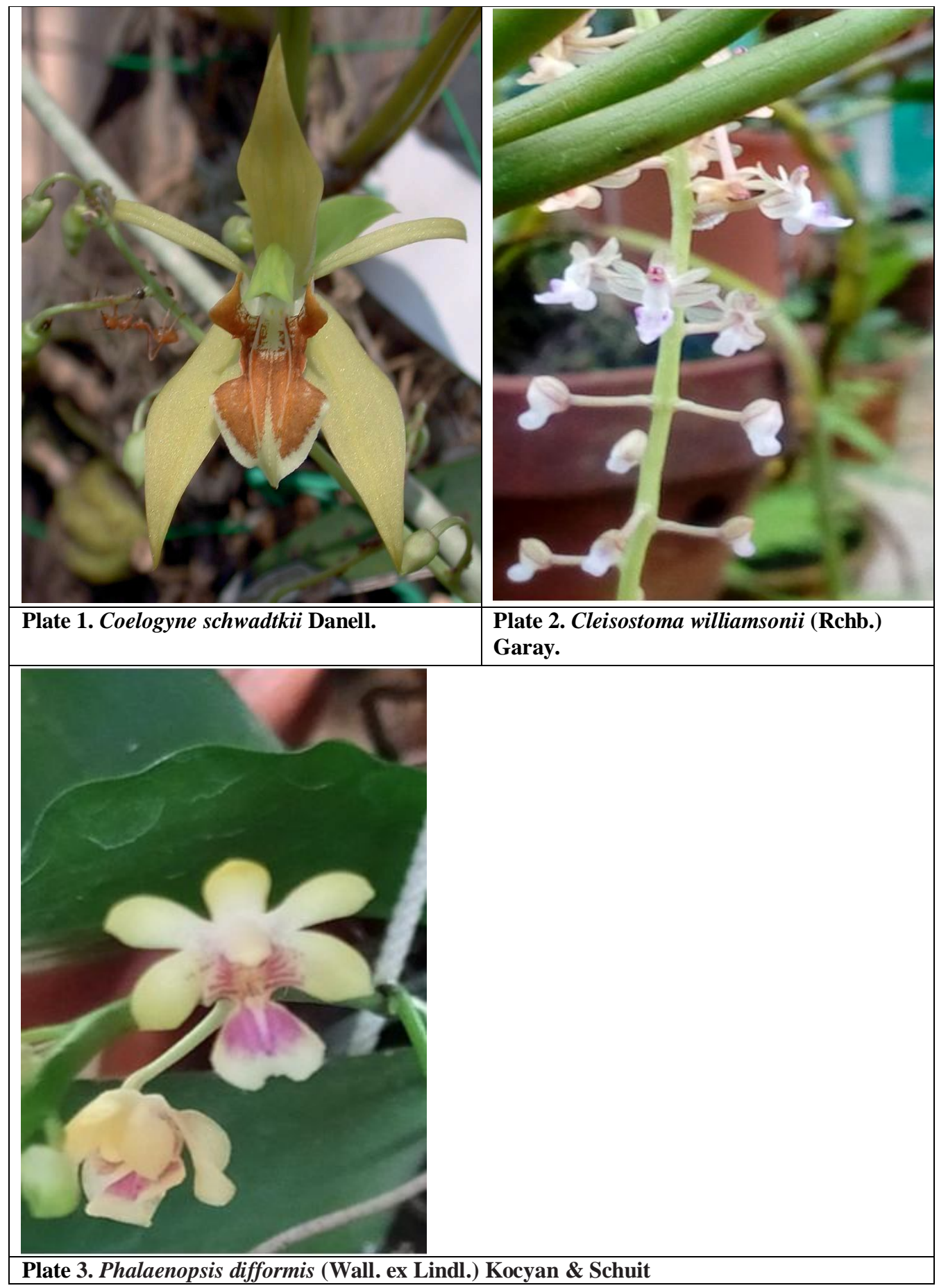




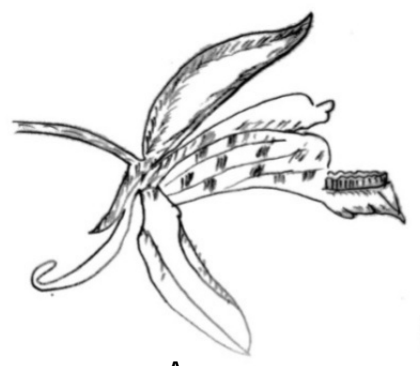

A
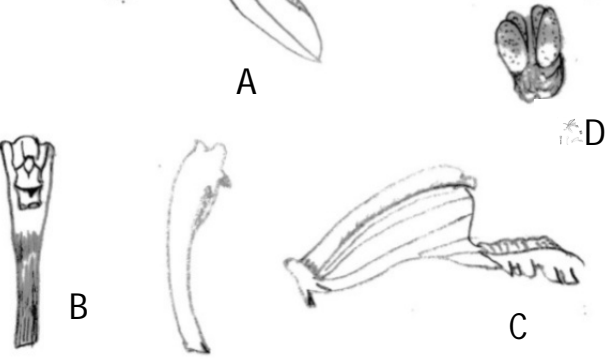

Fig. 1. Coelogyne schwadtkii Danell. A) flower; B) column; C) lip; D) pollinia and stipe.
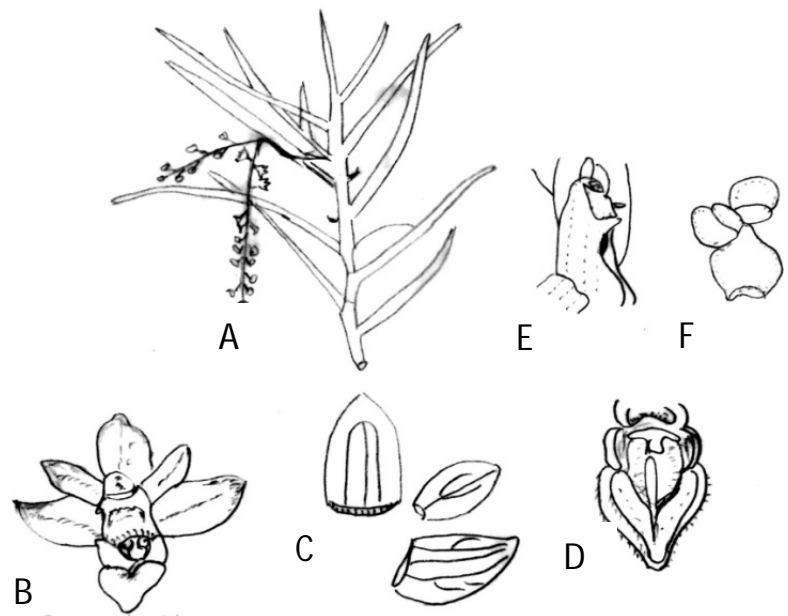

Fig. 2. Cleisostoma williamsonii (Rchb) Garay. A) habit; B) flower; C) spreading of sepal and petal; D) lip; E) column; F) pollinia and stipe 


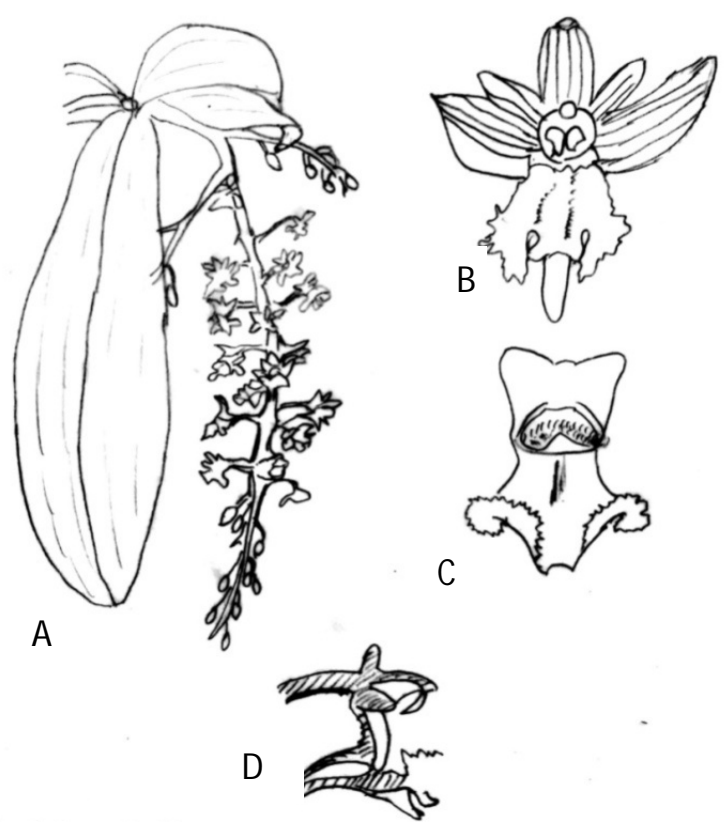

Fig. 3. Phalaenopsis difformis (Wall. ex Lindl.) Kocyan \& Schuit. A) habit; B) flower; C) labellum; D) column

\section{REFERENCES}

Ahmed, M. and Pasha, M.K. 1993. A taxonomic account of Thrixspermum Lour. (Orchidaceae) from Bangladesh. J. Asiat. Soc. Bangladesh Sci. 19(1): 35-42.

Ahmed, M. and Pasha, M.K. 1994. A taxonomic account of Hetaeria Blume (Orchidaceae) from Bangladesh. Chittagong University Studies, part II. Sci. 18(2): 179-182.

Ahmed, M. and Pasha, M.K. 1998. A taxonomic account of Luisia Gaud. (Orchidaceae) from Bangladesh. J. Bombay. Nat. Hist. Soc. 95: 301-306.

Ahmed, M. and Pasha, M.K. 1998a. Gastrochilus inconspicum (Hook.f.) Siedenf. (Orchidaceae) A new angiospermic record for Bangladesh. Bangladesh J. Bot. 27(2): 61-69.

Biswajit, C. 1987. Taxonomic studies of Orchids from Chittagong. Unpublished M. Sc. Thesis. Dept. of Botany, University of Chittagong. pp. 128.

Cai, J., Lui, X., Vanneste, K., Proost, S., Tsai, W.C. and Lui, K.W. 2015. The genome sequence of the orchid Phalaenopsis equistris. Nat. Genet. 47: 65-72.

Clayton, D. 2002. The genus Coelogyne : A synopsis. Royal Botanic Gardens, Kew, UK.pp.316

Datta, R.M. and Mitra, J.N. 1953. Common plants in and around Dacca. Bull. Bot. Soc. Bengal. 7(1 \& 2): 1-10.

Danell, E.Utbildning, H. 2016. A new orchid species from Southeast Asia Coelogyne schwadtkii Danell.Orchideen J.23:107.

Halim, M. and Khan, M.S. 1991. Eulophia mackinnoni Duthie (Orchidaceae) - A new record for Bangladesh. Bangladesh J. Bot. 20(2): 231-233.

Hegde, S.N. 1997. Orchid Wealth of India. Proc. Indian National. Sci. Acad. 63( 3): 229-224. 
Heinig, R.L. 1925. List of Plants of the Chittagong Collectorate and Hill Tracts - The Bengal Government Branch Press, Darjeeling, India, pp.84.

Hooker, J.D. 1885-1890. The Flora of British India. 5: 667-910. L. Reeve \& Co. Ltd., Kent, England.

Hooker, J.D. 1890-1894. The Flora of British India. 6: 1-198. L. Reeve \& Co. Ltd., Kent, England.

Huda, M.K. 2007. An updated enumeration of the family Orchidaceae from Bangladesh. J. Orchid Soc. India, 21: 35-49

Huda, M.K. 2008. Orchidaceae. In: Ahmed, Z.U., Hassan, M.A., Begum, Z.N.T., Khondker, M., Kabir, S.M.H., Ahmad, M., Ahmed, A.T.A., Rahman, A.K.A. \& Haque, E.U. (eds.). Encyclopedia of Flora and Fauna of Bangladesh. Vol. 12, pp (1-149). Asiatic Society of Bangladesh, Dhaka.

Huda, M.K. and Rahman, M.A. 1999. Some rare ornamental epiphytic orchids of potential horticultarul value. Biodiversity Newsletter Bangladesh 3(1): 2.

Huda, M.K., Rahman, M.A. and Wilcock, C.C. 1999. A preliminary checklist of orchid taxa occurring in Bangladesh. Bangladesh J. Plant Taxon. 6(1): 69-85.

Huda, M.K., Rahman, M.A. and Wilcock, C.C. 2001. Notes on the Orchidaceae of Bangladesh 1: some new records. Bangladesh J. Plant Taxon. 8(2): 9-17.

Khamum, M., Uddin, M.Z., Khan, M.S. and Hassan, M.A. 2001. Our present knowledge on the terrestrial orchidaceous taxa from Bangladesh. Bangladesh J. Plant Taxon. 8(2): 35-49.

Khan, M.S. and Halim, M. 1987. Bulbophyllum lilacinum Redley-A new angiospermic record for Bangladesh. Bangladesh J. Bot. 16(2): 203-205.

Khan, M. S. and M. Halim. 1991. Eulophia nuda Lindl. (Orchidaceae)- A new angiospermic record for Bangladesh. Bangladesh J. Bot. 20 (1): 81-83.

Kocyan and Schuiteman. 2014. Phalaenopsis difformis (Wallrich ex Lindley) Kocyan \&Schuit. Phytotaxa. 161: 67.

Lang, K., Chen, S., Luo, Y. and Zhu, G. 1999. Orchidaceae . In: Lang, K (Ed.), Fl. Reipubl. Popularis Sin. 17: 1-499.

Moyeen, M. 1982. Taxonomic studies in the family Orchidaceae from Bangladesh. Unpublished M.Sc. Thesis. Dept. of Botany, University of Chittagong. pp. 202.

Pant, B., Paudel, M.R., Chand, M.B. and Wagner, S.H. 2016. A Treasure Trove of Orchids in Central Nepal. Kirtipur: Central Department of Botany, Tribhuvan University, Kathmandu, Nepal.

Pearce, N.R. and Cribb, P.J. 2002. The flora of Bhutan. The orchids of Bhutan. Vol.3, Part 3. The Royal Botanic Garden Edinburgh (UK):

Pfi tzer, E. and Kraenzlin F. 1907. Coelogyne. In: A Engler (ed), Das Pflanzenreich 32: 49 - 56.

Prain, D. 1903. Bengal Plants. Vol.2.(Reprint 1966). Botanical survey of India, Calcuta, pp. 750772 .

Rahman, M.A. and Huda, M.K. 1998. Some threatened and endangered orchids of Bangladesh and their conservation. Biodiversity Newsletter 2(1): 3-4.

Rahman, M.A. and Huda M.K. 2001. Notes on the occurrence of Brachycorythis helferi (Reichb.f.) Summerh. - in south-east Bangladesh. Biodiversity Newsletter Bangladesh 5(1\&2): 3 .

Rahman, M.A., Huda M.K. and Rashid M.E. 2017. Orchid species diversity in Bangladesh and their revised Nomenclatural updates. Biodivers. Bull. Bangladesh 10:1-70.

Roxburgh, W. 1814. Hortus Bengalensis (nom. nud.). Boerhaave Press, Leiden (Holland).

Roxburgh, W. 1832. Flora Indica. Carey, W (Ed.). Vol. 3. Mission Press, Serampore, Calcutta, India.

Seidenfaden, G. 1978. Orchid genera in Thailand 6. Neottoideae. Kansk Bot. Ark. 32: 1-195. 
Seidenfaden, G. 1978a. Orchid genera in Thailand 7. Oberonia Lindl. and Malaxis Sol ex Sw. Kansk Bot. Ark. 33(1): 1-94.

Seidenfaden, G .1985. Orchid genera in Thailand 12. Dendrobium Sw. Opera Bot. 83: 26-57.

Seidenfaden, G. 1988. Orchid genera in Thailand XIII. Thirty three Epidendroid genera. Opera Bot. 89: 1-216.

Sinclair, J. 1956. The Flora of Cox's Bazar. East Pakistan. Bull. Bot. Soc. Beng., 9(2): 107-108.

Wallich, N. 1786-1854. A numerical list of dried specimens of plants in the East Indian Company's Museum. 